Jowita Żurawska-Chaszczewska

(Gorzów Wielkopolski)

\title{
O PORÓWNANIACH W JĘZYKU JÓZEFA KORZENIOWSKIEGO (NA PRZYKŁADZIE PORÓWNAŃ Z ŁACZNIKIEM JAK W POWIEŚCI „SPEKULANT”)
}

\begin{abstract}
The article is a contribution to the series of studies which investigate the idiostyle of Józef Korzeniowski, including the analysis of similes in 14 works by the writer. The author examines comparative constructions with conjunctions as/like in Korzeniowski's first novel and distinguishes grading and non-grading comparative statements, as well as textual and associative ones; comparandum and comparatum are also discussed.
\end{abstract}

\section{Key words}

style, writers' idiolect, comparison 
Pierwszą powieścią dojrzałego ${ }^{1}$ i uznanego dramatopisarza i pedagoga Józefa Korzeniowskiego jest napisany na początku grudnia 1845 r. utwór prozatorski „Spekulant”, którego akcja rozgrywała się od lutego $1843 \mathrm{r}$. do wiosny następnego roku². Na tle zabiegów spekulanta mariażowego Molickiego oraz historii wymuszonego przez rodziców małżeństwa Klary i Henryka ukazane zostały w niej zjawiska obyczajowe i społeczne współczesne pisarzowi - życie ziemiaństwa i szlachty na Podolu.

Analizując język pisarzy, badacze wśród środków językowo-stylistycznych współtworzących świat przedstawiony odnajdują porównania, które stanowią istotny składnik idiostylu twórców3 ${ }^{3}$. Porównanie rozumiem jako

\begin{abstract}
dwuczłonową konstrukcję semantyczną sprzęgniętą wewnętrznie za pomocą wyrażeń jak, jako, jak gdyby, na kształt, podobny, niby itp. Oba człony odznaczają się przy tym pewną wspólną cechą semantyczną, motywującą porównanie i stanowiącą jego podstawę tzw. tertium comparationis. W wyniku porównania przedstawione zjawisko zostaje zinterpretowane poprzez pryzmat zjawiska, z którym je zestawiono ${ }^{4}$,
\end{abstract}

a dzięki wskazaniu podobieństwa do innego zjawiska uwydatnione zostają właściwości opisywanego zjawiska.

Przedmiotem niniejszej analizy - jako cząstkowych badań porównań w powieściach Józefa Korzeniowskiego - są konstrukcje komparatywne współtworzące językowy i kulturowy obraz powieści „Spekulant”. Badaniu poddane zostały jednostki $\mathrm{z}$ formalnym wykładnikiem $\mathrm{w}$ postaci łącznika porównania, w tym porównania $\mathrm{z}$ nienacechowanym funktorem jak $(j a k o)^{5}$, oraz konstrukcje z koniunktorami złożonymi tak jak oraz skorelowanymi: tak... jak, równie... jak jako współtworzone przez łącznik jak. Zgodnie z badaniami B. Greszczuk:

\begin{abstract}
Indicativus podaje treść realną, rzeczywistą, pewną, natomiast coniunctivus - nierzeczywistą, hipotetyczną: możliwą lub nierealną, pomyślaną, wyobrażeniową, przypuszczoną, oczekiwaną lub wątpliwą. Porównania z jak, jako należą do indykatywnych, podczas gdy coniunctivus jest wprowadzany nie przez każde jakby, jakoby $y^{6}$.
\end{abstract}

\footnotetext{
1 „Gdy «Spekulant» wchodził na rynek księgarski, Korzeniowski rozpoczynał pięćdziesiąty rok życia. Debiut powieściowy był tu więc bardzo spóźniony” (Bachórz 1979, s. 12).

${ }^{2}$ Ibidem, s. 168.

${ }^{3}$ Kozaryn 2009, s. 135-136.

${ }^{4}$ Słownik terminów literackich 1988, s. 376-377.

${ }^{5}$ B. Greszczuk: „Otóż okazuje się, że jak przenika także do porównań pozytywnie komparatywnych, a norma zaczyna decydować o użyciu dopiero w XIX w. W szczegółach wygląda to następująco: Faza I do XVI wieku - powszechne niż. Faza II: XVI wiek - pojawia się jako//jak w obu typach porównań z comparatiwem, ale zdecydowaną przewagę ma niż. Faza III od XVII do połowy XIX wieku - silna ekspansja jako//jak w obu typach porównań z comparatiwem”. Greszczuk 1981, s. $46-47$.

${ }^{6}$ Ibidem.
} 
Dla egzemplifikacji powyższej próby $\mathrm{w}$ artykule przytoczono fragmenty tekstów $\mathrm{z}$ analizowanego utworu, opublikowanego w jedynym dotąd zbiorze dzieł wszystkich Józefa Korzeniowskiego (pod kierunkiem redakcji „Kłosów”) w Warszawie w $1871 \mathrm{r}^{7}$

\section{RODZAJE PORÓWNAŃ}

Spośród 262 konstrukcji wyekscerpowanych z powieści „Spekulant” w listach odnajdujemy 13 porównań (5\%), w partiach opisowych - 167 konstrukcji $(63,7 \%)$, a w dialogach - 82 porównania (31\%). Jak zauważa B. Mikołajczak:

porównania są szczególnie ważnym czynnikiem charakteryzacji wypowiedzi bohaterów, a ich występowanie w narracji jest następstwem harmonii stylistycznej między obu częściami tekstu ${ }^{8}$.

Korzeniowski kieruje swoje powieści zawierające elementy tendencyjne do szerokiego grona odbiorców, stąd w jego utworach konstrukcje językowo-stylistyczne ułatwiające zrozumienie założeń autorskich. W narracji nietrudne do odczytania i zinterpretowania konstrukcje komparatywne mają przybliżyć świat przedstawiony, jak również zabawić projektowanego czytelnika. W dialogach przybliżają język wypowiedzi bohaterów do mowy zwyczajnej, codziennej, pozbawionej patosu, a więc znowu bliskiej odbiorcy.

W badanej grupie porównań w powieści „Spekulant” wyodrębnić można również konstrukcje gradacyjne, które za B. Greszczuk rozumiem jako sygnalizujące „zależność między dwoma przeciwstawnymi stopniami gradacji: comparativem i positiwem lub trzema: superlatiwem, comparatiwem i positiwem". W analizowanej powieści jednostki tego typu z funktorem jak nie są liczne, odnajdujemy ich bowiem 10, np. „Zdala jednak jaśniała żółta massa $\mathrm{z}$ białemi kolumnami i więcej jak na milę w około świeciła dom pana Chorążego" (s. 14) ${ }^{10}$. Dzięki nim pisarz doprecyzowuje konstrukcję powieściowego uniwersum, np. oddając proporcje między miejscami, wyzyskuje również porównania gradacyjne do uwypuklenia realizmu akcji, np. podając różnicę cen, jak w przykładzie: „powiem jasne panie, że taniej pszenicy, jak ta, taniej jak dwa ruble srebrne nie można dostać" (s. 82) czy charakteryzuje bohaterów, w tym ich uczucia i charaktery, co ilustruje cytat: „bo on więcej kocha pieniędzy, jak córkę" (s. 64).

\footnotetext{
${ }^{7}$ Korzeniowski 1871,1 , s. 1-148.

${ }^{8}$ Mikołajczak 1976, s. 106.

${ }^{9}$ Greszczuk 1981, s. 42.

${ }^{10}$ Po cytacie podaję numer strony $\mathrm{z}$ analizowanego wydania.
} 
W „Spekulancie” przeważają porównania niegradacyjne „wyrażające zależność na jednakowym szczeblu gradacji, nie zawierające form comparatiwu lub superlatiwu"11, których wyekscerpowano 252 (96\%). Pisarz podejmuje tu próbę wskazania odbiorcy swojego toku rozumowania i narzucenia bądź zasugerowania mu postrzegania rzeczywistości powieściowej, a przez nią i relacji w świecie pozapowieściowym. Nie ogranicza to oczywiście wyobraźni czytelniczej, lecz wyraźnie ją ukierunkowuje.

Ze względu na odwołania do sfery tekstowej oraz pozatekstowej, kulturowej porównania możemy podzielić na tekstowe i asocjacyjne. Tekstowymi nazywamy takie konstrukcje porównawcze, w których oba człony są elementami tekstu ${ }^{12}$. Zdaniem S. Mikołajczaka:

\begin{abstract}
W porównaniach tekstowych napięcie niemal nie istnieje, porównanie jest puste, tautologiczne, ich człon porównujący odnosi podstawę porównania do wiedzy wypływającej z tekstu i do wiedzy o bohaterach, akcjach, zdarzeniach stanowiących elementy składowe tkanki utworu ${ }^{13}$.
\end{abstract}

W porównań tekstowych w członie porównującym wymieniane są wprost osoby, fakty, zdarzenia, przedmioty itp., które wprowadzają nowe treści, np. porównaniem: „O! i owszem, proszę mnie zawsze tak nazywać, jak w Odessie - rzekła żywo" (s. 27) autor odsyła czytelnika do ledwie zarysowanego w utworze czasu spędzonego przez chorążynę i jej córkę w dużym mieście, gdzie panienka pobierała nauki; ponieważ wówczas obie często spotykały się z marszałkiem. Konstrukcja dopełnia obrazu zażyłości, bliskości i zaufania między bohaterami.

Jedną z funkcji porównań tekstowych jest utrwalanie kluczowych elementów fabuły, stąd przywołują wydarzenia, sytuacje dobrze znane bohaterom, których znaczenie czytelnicy rozumieją dzięki kontekstowi. W „Spekulancie” niecierpliwe czekanie na spadek przez oboje małżonków Barskich, którym grozi licytacja, podkreśla autor porównaniem: „Gdy się nad tem zastanawiał, przyjechała siostra, a za nią w parę dni jej maż, dał dowiedzenia się, jak ukończył interes w Odessie, który ją, równie jak i jego interesował" (s. 33).

Dzięki porównaniom tekstowym powieściowy świat wykreowany przez Korzeniowskiego wydaje się spójny, rozległy, wzmacniają one przekonanie o realizmie przedstawionych miejsc, bohaterów, akcji, dopełniając zasadę prawdopodobieństwa życiowego.

\footnotetext{
${ }^{11}$ Greszczuk 1981, s. 42.

${ }^{12}$ Mikołajczakowa i Mikołajczak 1996, s. 73.

${ }^{13}$ Mikołajczak 2001, s. 93-94.
} 
Znacznie bardziej interesujące $w$ utworach Korzeniowskiego oraz innych pisarzy są porównania asocjacyjne, gdyż jak twierdzą B. Mikołajczkowa i S. Mikołajczak, stanowią one właściwy środek stylistyczny współkształtujący tkankę językową utworu ${ }^{14}$. J. Korzeniowski wprowadza w konstrukcjach porównawczych komponenty leksykalne ${ }^{15}$, odsyłające do działań człowieka, artefaktów, świata przyrody ożywionej i nieożywionej.

W konstrukcjach porównawczych pisarz - podobnie jak i inni twórcy odwołuje się do praktyki życiowej projektowanego odbiorcy, co potwierdzają obserwacje D. Kozaryn: „Odwoływanie się zarówno do obiektów porównań, jak i w ich nośnikach do tych samych kręgów znaczeniowych nie dziwi. Porównanie zakłada przecież szukanie podobieństwa do czegoś znanego"16. Przywołanie realiów pozapowieściowych jest mocno zakorzenione w tradycji literackiej, np. zdaniem K. Siekierskiej:

Zgodnie ze wskazaniami poetyki i retoryki starożytnej, zwłaszcza Kwintyliana i Cycerona, których poglądy były szczególnie popularne w wieku XVII, zarówno Potocki, jak i Pasek obiekty, do których porównują jakiś przedmiot (...) czerpią $\mathrm{z}$ najbliższej otaczającej ich rzeczywistości ${ }^{17}$.

Służą one bowiem przede wszystkim zrozumieniu opisywanych zjawisk, uzupełniają zarówno przekaz autora, szukającego porozumienia $\mathrm{z}$ odbiorcą, jak i pozwalają temu ostatniemu odczytać intencję pisarza oraz wypełnić przekaz własnymi treściami, skojarzeniami, a wraz z nowymi przeżyciami i doświadczeniami - odczytywać tekst ciągle na nowo. Dzięki porównaniom opis świata przedstawionego staje się bardziej plastyczny, jednocześnie bardziej wyrazisty i konkretny, a przy tym otwierający możliwość indywidualnej interpretacji, np. „Usiedli obaj i pojechali szybko, rozmawiając jak dwaj przyjaciele, którzy po długiem niewidzeniu spotykają się niespodziewanie na drodze" (s. 45).

\section{KOMPARANS - POLA TEMATYCZNE}

Konstruując porównania, Korzeniowski często przywołuje obraz codziennych ludzkich spraw: funkcjonowania w społeczności, rodziny, działań, pracy itp. Komponenty leksykalne występujące w członie określającym lub z nim

\footnotetext{
${ }^{14}$ Mikołajczakowa i Mikołajczak 1996, s. 74.

${ }^{15} \mathrm{Za}$ J. Ścibek uznaję, za komponent leksykalny część składową komparacji, jedno- lub wielowyrazową. Ścibek 2013, s. 99-121.

${ }^{16}$ Kozaryn 2009, s. 141.

${ }^{17}$ Siekierska 1981, s. 243.
} 
tożsame odwołują się zarówno do świata ludzi, jak i przyrody ożywionej i nieożywionej oraz artefaktów. Możemy je przydzielić do następujących pól:

1. porównania $\mathrm{z}$ komponentem odwołującym się do człowieka

a) artystów

np. „Chorąży chcąc naprawić to, według jego myśli, obojętne przyjęcie, oszczędzając jedynego człowieka, który tak jawną oddaje mu sprawiedliwość, jak my często oszczędzamy tego poczciwca, co o nas łaskawe pisze artykuły, zawołał” (s. 46); „Wiadomo jest, jakie wrażenie robi atmosfera sypialnego pokoju młodej i ładnej kobiety, a szczególniej w takich głowach, jak głowy poetów. (...) Gdy się ujrzał w tem miejscu tak pełnem tajemnicy” (s. 110);

b) przestępców

np. „i uśmiechając się w duszy nad ufnością biednej dziewczyny, którą miłość, jak złodziej z zasadzki, napadł nagle i niespodziewanie, nie myślał o niej wcale" (s. 33);

c) życia rodzinnego

np. „Gdy nazajutrz pan August po kawie wyjeżdżał, wyjeżdżał jak z domu, jak od rodziny, tak go żegnał Chorąży, tak Chorążyna, tak panna Klara” (s. 50);

d) przeżyć

np. „Biedna panna Klara raz pierwszy w życiu, które dotąd było tak swobodne, tak wesołe, poczuła ten ból przenikliwy, z jakim wchodzi do serca kobiety każde słowo, które jak mgła brudna osada na jasnym obrazie kochanka i czarne na nim zostawia plamy" (s. 21);

e) czynności

np. „zrobił on w umyśle i sercu panny Klary znaczną rewolucyą, i stał się równie użytecznym, jak owo dojmujące świdrowanie igiełką $w$ palcu, kiedy się z niego wyjmuje ostra trzaseczka, która wpijała się coraz głębiej i bolała coraz mocniej" (s. 128);

f) znajomości literatury

np. „Przy waszej rozmowie zasnąłbym tak smaczono, jak Walenrod przy pieśniu Halbana” (s. 19); 
g) znajomości mitologii

np. „Zasnę jak Herkules u nóg Omfali” (s. 19);

h) tematyki wojskowej

np. „Jak wódz zmierzający ważną ekspedycyą, robi wszelkiego rodzaju przygotowania, tak i pan Augustyn nie tylko myślał o zewnętrznych środkach podobania się” (s. 3)/ „Z tym głosem przeraźliwym, głupim, i przechodzącym po kudłatych szeregach jak plutonowy ogień, mięszały się krzyki właścicieli, łajania pastuchów, szczekanie psów i charkotanie żydów, którzy jak powietrze obejmowali wszystko i byli wszędzie" (s. 86);

i) religii i wierzeń

np. „pokazał się między lipami kościołek biały i ładny, a na nim krzyż pozłacany odbił słońce i zajaśniał, jak wróżba pociechy” (s 119)/ „Gdyby zaraz z początku pan Kasper był przy nim stanął, widok tego człowieka, któremu tak wielką krzywdę wyrządził, którego się bał jak djabła, byłby go pewnie powstrzymał” (s. 88); „Rozum szeptał, perswadował, ale serce kochające, niewierne jak Tomasz, chciałoby widzieć ranę i jej dotknąć” (s. 105);

j) wydarzeń historycznych

np. „W tej grupie badanych jednostek odwołania do dziejów niedawnych, jak w przykładzie: „Abramko zdjął jarmułkę i ukłonił mu się tak, jak się kłaniał Fouché Napoleonowi, wjeżdżającemu do Niemiec przed bitwą pod Lützen” (s. 60);

k) zabaw

np. „Obeznany z dawna ze wszystkiemi manewrami strategii miłosnej, postanowił w potrzebie użyć ich jako środka, ale oraz odrzucić, dopiąwszy swego, jak odrzucał kartę, która już wygrała" (s. 4);

l) choroby i śmierci

np. „panna Klara siedziała obok niego ze spuszczoną głową i twarzą jak trup bladą” (s. 21)/ „Biedna dziewczyna, usłyszawszy rozkaz, upuściła robotę z rąk, drżenie jakieś gwałtowne schwyciło całe jej ciało, dzwoniły te śliczne i białe ząbki jak w dreszczu febrowym, i mgła jakaś stanęła przed jej oczyma" (s. 99); 
2. porównania $\mathrm{z}$ komponentem odwołującym się do przyrody:

a) przyrody ożywionej:

- fauny

np. „Te trzy słowa: posag za życia, wsi za życia, nim umrzesz, tłukły się po jego głowie, jak trzy bąki puszczone silnie w próżnej izbie i uderzające się z hukiem to o ścianę, to o siebie” (s. 98)/ „Tu i owdzie biegały krakowskie bryki, pełne żydów, żydówek i dzieci, które ztamtąd, jak wróble z gniazda, wyciągały kudłate główki” (s. 86);

- flory

np. „Ten ton i wyraz zmięszały ją cokolwiek, ale krzepiąc się i najeżając kolce, w które nasze śliczne Polki równie nieskąpo uposażone, jak róże, do których i z tego względu podobne, rzekła z przyciskiem” (s. 109)/ „Te wady przy innem wychowaniu, przy gruntownej nauce, przy jakiemścś ważniejszem zajęciu, któreby mu pokazało wyższe cele, byłoby może wzięły inny kierunek, ale to życie, na którem przepędził pierwszą młodość, odpoetyzowała zupełnie jego duszę, a jego serce jak śliwka węgierka, która przeszła przez wiele rąk, zmięte i zgniecione straciło całkiem swą dziewicza barwę" (s. 2);

b) przyrody nieożywionej

np. „pan August nikogo nigdy nie żałował, a przytem wiedział z doświadczenia, że łzy, które dawniej wyciskał kochającym go kobietom, były jak deszcz padający na łąkę. Jak po nim trawa zieleńsza, tak uważał, że po płaczu miłość bywa gorętsza i głębsza” (s. 41); „Panna Klara chodziła po pokoju z głową zwieszoną (...) przypominała wszystkie bolesne uczucia już doznane i zaglądała w przeszłość zimną, pustą, jak step zamarzły” (s. 107); „Jego umysł i serce, bogate jak Podolska niwa, dobrze uprawione i przygotowane w Krzemieńcu, przyjęły wdzięcznie siejbę, jaką w niej później świat, życie społeczne i dalsze okoliczności rzuciły” (s. 29); „Dwie rzeczy tak różne, jak niebo i ziemia - mówił dalej kulawy djabeł; - dwie istoty tak do siebie niepodobne; jak pani Hieronimowa do swojego portretu, bo ona brzydka duszą i ciałem, a portret piękne ma rysy i anielski wyraz" (s. 38); 
3. porównania $\mathrm{z}$ komponentem odwołującym się artefaktów

a) przedmiotów i ich użycia

np. „Słowa te przeszyły marszałka jak ostre szydło” (s. 32)/ „Obeznany $\mathrm{z}$ dawna ze wszystkiemi manewrami strategii miłosnej, postanowił w potrzebie użyć ich jako środka, ale oraz odrzucić, dopiąwszy swego, jak odrzucał kartę, która już wygrała” (s. 4); „słupy tylko werstowe sterczały, i jak wskazówki busoli, dawały kierunek furmanowi po tem białem i puszystem morzu" (s. 10);

b) budowli i ich części

np. „Ale spostrzegłszy, że panna Klara zbladła jak ściana, (...) przyciągnął ją do siebie, pocałował i rzekł:" (s. 58).

Interesująca i oryginalna jest grupa konstrukcji porównawczych, w których pojawia się komparans z kręgu tematyki wojskowej, bowiem w „Spekulancie” pisarz wyzyskuje podobieństwo strategii prowadzenia wojny do robienia interesów oraz spekulacji matrymonialnej. Z kolei w grupie porównań przywołujących nazwy związane $\mathrm{z}$ wiarą i religią autor wyzyskuje nieprzystawalność obu członów porównania - istoty ludzkiej i elementu religijnego, ujawniając i potęgując nietypowy charakter konstrukcji.

Przywołując nazwy własne postaci historycznych i literackich, Korzeniowski odwołuje się bardziej do wiedzy niż doświadczenia. Zakłada albo znajomość postaci i wydarzeń, albo też determinację odbiorcy, który uzupełni wiadomości; narrator w powieści „Spekulant” sugeruje czytelniczkom poproszenie bliskich, wykształconych mężczyzn o objaśnienie niezrozumiałych fragmentów.

Korzeniowski sięga tu do świata przyrody znanej z otoczenia potencjalnego czytelnika. Konstrukcje z komparansem odnoszącym się do świata zwierząt służą przede wszystkim kształtowaniu plastyki opisu i współkreowaniu wizerunku postaci. Skojarzenia będące podstawą porównań wydają się odpowiednio dobrane z powodu trafności i obrazowości. Ponadto autor wyzyskuje symbolikę zwierząt, którym przypisywane są określone zachowania, przymioty, cechy i własności, np. odwaga = jak lew; bierność $=$ jak owce ${ }^{18}$. Porównań z komponentem florystycznym jest niewiele; są to przede wszystkim banalne odwołania do kwiatów jako symbolu kobiecego piękna i wdzięku. W grupie porównań odniesionych do świata przyrody nieożywionej Korzeniowski wykorzystuje komparansy zawierające nazwy związane ze światem przyrody nieożywionej, niewymagające kompetencji kulturowych.

\footnotetext{
${ }^{18}$ Kopaliński 1990, s. 194-196, s. 292-294.
} 


\section{KOMPARAT - POLA TEMATYCZNE}

Porównania wyekscerpowane z powieści „Spekulant” uwypuklają przede wszystkim cechy człowieka i jego zachowanie, współkreując wizerunki bohaterów. To bowiem człowiek znajduje się w centrum uniwersum przedstawionego badanych utworów, natura pełni tu rolę drugorzędną: urealnia świat przedstawiony i w niewielkim stopniu buduje nastrój dzieła. W analizowanym utworze, jak również w pozostałych 13 powieściach Korzeniowskiego, dominuje antropocentryczny punkt widzenia.

$\mathrm{Z}$ analizowanego materiału wyekscerpowano konstrukcje banalne, schematyczne, choć pojawiają się również elementy zaskakujące świeżością. Zauważamy tu dwa typy ujęcia komparatu: jego hiperbolizację, uwydatnienie, spotęgowanie cech postaci oraz „ujęcie deprecjonujące, oparte na kontraście jako podstawowej relacji pomiędzy obiektem określanym i określającym”"19.

\section{Porównania charakteryzujące człowieka}

Najliczniejszy zbiór tworzą konstrukcje, w których przedmiotem porównania jest człowiek, a których celem jest uwydatnienie jego cech fizycznych, psychicznych i przeżyć. Przez ich zastosowanie autor hiperbolizuje zalety lub deprecjonuje wady postaci, sięgając po kontrast między obiektem określanym i określającym.

a) porównania charakteryzujące wygląd postaci

Konstrukcje porównawcze uplastyczniają wygląd postaci, idealizując urodę lub wyszydzając braki zarówno kobiet, jak i mężczyzn. Korzeniowski podkreśla fizyczne uroki, wdzięk i zmysłowość bohaterek, których zarówno cechy charakteru, jak i walory ciała budzą podziw i zazdrość otoczenia, natomiast brzydotą ciała sugeruje wady i niewłaściwe obyczaje.

Zalety kobiecego ciała podkreślają odwołania do kwiatu - róży ${ }^{20}$, konotującej piękno i delikatność, np.

Gdy w tłusty czwartek o godzinie 8-mej wieczorem panna Klara, wystrojona, świeża jak róża (...) weszła obok męża do pełnej już sali prezesowej, wszystkich oczy zwrócily się z podziwieniem na piękną parę (s. 134-135).

Analogia ta, choć mało oryginalna, wyraźnie akcentuje cechy pożądane, podobnie w przykładzie: „może ledwie spojrzy na twarzyczkę jej owalną

\footnotetext{
${ }^{19}$ Ścibek 2013, s. 111.

${ }^{20}$ Bartmiński 2009, s. 99.
} 
i świeżą, na jej oczy, które umiały patrzeć całą duszą, na jej usta jak jagoda rumiane, i na jej rączki jak śnieg białe" (s. 7). Odwołania te uwydatniają czystą, dziewiczą urodę, bez eksponowania zmysłowości, a zdaniem A. Nowakowskiej:

Porównania nawiązujące do morfologii roślin wykorzystywane są w ogólnej charakterystyce wyglądu osób. Powab młodych kobiet zestawiany jest $\mathrm{z}$ pięknem kwiatów (...) Nazwy najbardziej efektownych części rośliny służą jako odniesienia w licznych komparacjach podkreślających urodę i wdzię $k^{21}$.

Autor porównaniami sugeruje również brzydotę, a nawet chorobę, np.:

Powtóre - rzekł pan Kasper (...) - nie lakieruje sobie twarzy i nie różuje się, bo ma czerwoność naturalną, złożoną z drobniutkich pryszczyków pochodzących od złego życia, i które zlawszy się, jak gwiazdeczki drogi mlecznej, w jednę massę, stanowią wieczny rumieniec (s. 141).

Z dużą dozą prawdopodobieństwa można przyjąć, że autor sygnalizuje chorobę weneryczną, a przez nią wskazuje moralne zepsucie bohaterki i jej narzeczonego, tytułowego spekulanta Augusta Molickiego.

Umiejętnie wprowadzając $\mathrm{w}$ tok narracji konstrukcje porównawcze, Korzeniowski wykpiwa zarozumiałość, czy wręcz megalomanię postaci przez skontrastowanie szpetnego, wątłego ciała młodego poety Pawła z wyglądem mitologicznego Herkulesa, gdy niezbyt urodziwy, zaniedbany wierszokleta mówi o sobie: „Zasnę jak Herkules u nóg Omfali” (s. 19). Porównanie to deprecjonuje słabowitego młodzieńca, przewrotnie potęgując wrażenie braku zalet jego ciała i ducha.

Ironiczne przywołanie sfery profanum, pełnej grozy i niesamowitości, wyzyskuje autor w porównaniu sługi do czarownika, gdy ten przygotowuje poncz dla grających w karty gości:

$\mathrm{Na}$ okrągłym stole $\mathrm{z}$ boku stała waza $\mathrm{z}$ kipiątkiem, leżał cukier, cytryny, czajnik $\mathrm{z}$ herbatą, butelki $\mathrm{z}$ winem, $\mathrm{z}$ romem, szklanki, i t. d., a przy nim stał Franciszek rzucający garścią cukier do wazy, i wyglądający jak czarownik za kłębami pary, która $\mathrm{z}$ nich buchała (s. 115).

Porównanie staje się tu elementem komentarza, interpretacji hulaszczego życia młodzieży, zabawiającej się szulerką oraz zimnego serca Molickiego, który zamiast cierpieć po stracie ukochanej, gra w karty.

b) porównania charakteryzujące cechy wewnętrzne bohaterów i ich uczucia

\footnotetext{
${ }^{21}$ Nowakowska 2005, s. 73.
} 
Pozostając w kręgu porównań z comparandum odnoszącym się do człowieka, można wskazać konstrukcje uwydatniające i potęgujące uczucia.

Odnajdujemy tu konstrukcję mającą hiperbolizować zalety Henryka Zabrzezińskiego, jak: „Jego umysł i serce, bogate jak Podolska niwa, dobrze uprawione i przygotowane w Krzemieńcu, przyjęły wdzięcznie siejbę, jaką w niej później świat, życie społeczne i dalsze okoliczności rzuciły” (s. 29), która jednocześnie uwypukla zarówno ogólne wrażenie kryształowego charakteru bohatera, jak i jego dobrego wykształcenia oraz obycia. Jednocześnie autor podkreśla związek postaci z Podolem.

Przeciwieństwem Henryka jest August Molicki, tak charakteryzowany przez narratora już na drugiej stronie powieści:

\begin{abstract}
Te wady przy innem wychowaniu, przy gruntownej nauce, przy jakiemścś ważniejszem zajęciu, któreby mu pokazało wyższe cele, byłoby może wzięły inny kierunek, ale to życie, na którem przepędził pierwszą młodość, odpoetyzowała zupełnie jego duszę, a jego serce jak śliwka węgierka, która przeszła przez wiele rąk, zmięte i zgniecione straciło całkiem swą dziewicza barwę (s. 2).
\end{abstract}

Porównanie wzmacnia kontrast między ukrytą wiedzą o prawdziwych wadach i zamiarach Augusta a autoprezentacją młodego człowieka, który $\mathrm{z}$ wyrachowania stał się pewnym powagi i obyczajów, co z kolei Korzeniowski sygnalizuje konstrukcją porównawczą: „To raz przedsięwziąwszy, zapomniał

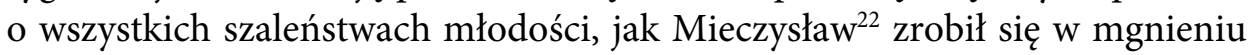
oka starym" (s. 3).

Autor porównaniem potęguje odwagę i determinację łagodnej zazwyczaj chorążyny, zdolnej do wszystkiego dla dobra dziecka, wyzyskując symbolikę lwicy jako groźnej, broniącej młodych matki. Tak postrzega bohaterkę plotkarz Kasper Barski:

Bo ostrzegam się, że ta delikatna, łagodna, dobra kobieta stanie i nasroży się jak lwica nawet przeciwko swemu mężulkowi, gdyby chciał dla pieniędzy poświęcić szczęście jej dziecka (s. 39).

Miłość chorążyny docenia córka, której zaufanie i przywiązanie do opiekunki ilustruje Korzeniowski porównaniem, w którym comparatum wywodzi się ze sfery sacrum. Klara mówi: ,ja ci przysięgam na ten święty obraz Matki Boskiej, że we wszystkiem będę ci posłuszną, boś ty dobra jak anioł i kochasz mnie więcej, niżelim ja warta" (s. 18). Tę prawie bałwochwalczą miłość, usprawiedliwioną jednak wielkim poświęceniem, podkreśla również narrator:

22 Mieczysław Stary „(1126-1206) książę wielkopolski, którego współcześni nazwali «starym» z powodu powagi i surowości obyczajów”. Za przypisem w: Korzeniowski 1954, s. 408. 
Panna Klara zaś była tak szczęśliwa, żeby gotowa była jechać do Niedolipia nie tylko przez Bałtę, ale nawet na Wiatkę, byle tylko z matką, którą także czciła jak bóstwo, byle z panem Augustynem, który opanował jej myśl i serce (s. 9).

Kasper Barski, szwagier tytułowego spekulanta, potrafi zdobywać informacje i umie je odpowiednio wykorzystać, piętnując wady okolicznych mieszkańców. Złośliwość i talent plotkarski autor hiperbolizuje konstrukcją w przykładzie: „Zwłaszcza po dobrym obiedzie, gdy jeden i drugi kieliszek wina był w głowie, zaostrzał się jego język, i z dziwną szybkością, jak kosa dobrego kosiarza, podcinał wszystko, co spotkał" (s. 34).

Cierpliwości w dotarciu do niegodziwego celu nie postrzegał Korzeniowski jako zalety. Negatywny bohater August Molicki, którego marzeniem jest jedynie bogaty ożenek, szykuje się do zrealizowania go jak wojskowy planujący wojnę, starannie obmyślając plan i układając taktykę. Warto tu podkreślić trafność skojarzenia autora, konsekwentnie porównującego planowanie małżeństwa dla pieniędzy do kampanii wojennej, co ilustruje cytat: „Jak dobry generał, któremu o to szło, aby się odwagą popisał, pan August nie śpieszył; czekał, czekać cierpliwie, jak czekają spekulanci dobrej szansy, jak czekają koty zbliżania się łupu właśnie pod miarę ich skoku" (s. 59). Deprecjonując zamierzenia postaci, w porównaniu spiętrzonym Korzeniowski przywołuje wskaźniki leksykalne konotujące obłudę (spekulanci) i agresję (kot, łup).

Ponadto cynizm i okrucieństwo mariażowego spekulanta wyróżnia autor konstrukcją porównawczą, którą ten pragnie usprawiedliwić swoje postępowanie: „Bo ostrzegam pana, że wkrótce wszyscy mówić będą głośno, tak jak teraz wszyscy tylko myślą, że małżeństwo jest spekulacyą, nic więcej” (s. 92), wbrew opinii kolegów, potępiających ten sposób życia i zarabiania.

Stan emocjonalny głównej bohaterki Klary, czystość uczucia, wrażliwość oraz ból zawiedzionej miłości ilustruje konstrukcja komparatywna:

Biedna panna Klara raz pierwszy w życiu, które dotąd było tak swobodne, tak wesołe, poczuła ten ból przenikliwy, z jakim wchodzi do serca kobiety każde słowo, które jak mgła brudna osada na jasnym obrazie kochanka i czarne na nim zostawia plamy (s. 21).

W kolejnym przykładzie Korzeniowski wyzyskuje podobieństwo między nieufnością rozczarowanej kobiety a biblijną historią Tomasza Apostoła: „Rozum szeptał, perswadował, ale serce kochające, niewierne jak Tomasz, chciałoby widzieć ranę i jej dotknąć” (s. 105). I tak jak w przypadku świętego, Klara ze „Spekulanta” musi sama doświadczyć, w tym wypadku zdrady ukochanego, aby uwierzyć swoim bliskim. 
c) porównania charakteryzujące zachowanie i działanie postaci

Konstrukcje porównawcze dynamizują opis zachowań bohaterów, zwiększają obrazowość opisów, sugerując wykonywane gesty i mimikę postaci; przez spotęgowanie ruchu lub sygnalizowanie jego braku pisarz przemawia do wyobraźni i doświadczenia projektowanego czytelnika.

Wierny realizmowi Korzeniowski i tu przywołuje w porównaniach skojarzenia utarte, niewymagające szczególnych kompetencji kulturowych, ale odwołujące się do doświadczeń i wyobraźni czytelnika. W opisie: „Panna Klara w białej jak śnieg sukni, z zielonym wieńcem na głowie, z bogatym woalem, który zwieszał się od jej głowy i spadał z tyłu do ziemi, blada i piękna, jak posąg z marmuru, stanęła obok matki, nieruchoma jak posąg” (s. 105) dwukrotne sięgnięcie po komparans $\mathrm{z}$ kręgu artefaktów: posąg/posąg $\mathrm{z}$ marmuru $\mathrm{w}$ opisie ślubu, oddaje brak uczuć do narzuconego narzeczonego Henryka, a jednocześnie wzmacnia kreację rozpaczy Klary za ukochanym i jej determinacji, aby nie dopuścić do zaaranżowanego małżeństwa. Jednocześnie ów uwypuklony bezruch intryguje czytelnika, czekającego, jak postąpi zmuszana do ślubu dziewczyna.

Urodę, bogactwo, wdzięk Klary jako młodej mężatki uwypukla autor w opisie balu porównaniem innych młodych kobiet, tu - panien, do stada owiec, co egzemplifikuje cytat: „młode panny zbiły się w kupki, jak owce, i patrzyły w milczeniu” (s. 175). Korzeniowski wykpiwa bierność dziewcząt, łączącą się z zazdrością na widok marszałkowej, wyzyskując kontrast między ich zachowaniem a pewnością siebie szczęśliwej Klary.

Ujęcie deprecjonujące, oparte na kontraście jako relacji między obiektem określanym i określającym zauważamy w opisie zachowania postępującego nieludzko Molickiego. Autor wyzyskuje negatywną konotację leksemu złodziej, bowiem od początku powieści spekulant mariażowy August jest przestępcą, który dla pieniędzy depcze wartości moralne i rodzinne, co ilustruje przykład: „Wstrząsnął się pan August, jak złodziej, schwytany na uczynku” (s. 67).

Porównania wzmacniają obraz zmagań w różnych sytuacjach życiowych, w których znaleźli się bohaterzy powieści Korzeniowskiego.

Konstrukcje komparatywne ilustrują plany finansowe, a przez to podłość i wyrachowanie Molickiego. W cytowanym przykładzie ujęcie deprecjonujące postępowania bohatera oparte jest na kontraście między przyziemnymi pragnieniem bezwstydnego oszusta a kosmiczną potęgą: 
Niedolipie były piękną rezydencyą, że tę ogromną bogatą wieś okrążyły jeszcze trzy inne wsie bogatym wieńcem, i sytuacyą pana Chorążego dosuwały do owego uroczego miliona, który z całym szeregiem zer swoich jak kometa $\mathrm{z}$ ognistym ogonem, krążył ciągle po sferze jego głowy (s. 5).

Zamiary Molickiego uwypukla Korzeniowski comparatum związanym ze światem zwierząt, które ilustruje marzenia o wielkim majątku (posagu) mnogością stada ptaków i ich wielkością:

wyszedł do ogrodu, stanął oparty o drzewo, podniósł melancholicznie oczy w górę i wpatrywał się w jedność z sześciu zerami, które ciągnęły się jak stado żórawi po nad jego głową, coraz oddalały się, malały do wielkości wróbli, komarów, i nareszcie znikły w obłokach (s. 103-104).

W analizowanym materiale odnajdujemy również konstrukcje odnoszące się do działalności twórczej. Opisywany z sympatią, ale i pewną ironią, młody poeta Paweł cierpi męki, gdyż brakuje mu i talentu, i wykształcenia. Stąd jego niby wzniosłe próby pisarskie autor porównuje do zwykłego przedmiotu: „i układał z okazyi wypadków, których był świadkiem, to ballady, to przerabiał je na sonety, to potem ten sonet, jak gummę elastykę, chciał rozciągać do całego poematu" (s. 110). Różnicę między skromnymi dokonaniami tej postaci a uznanymi twórcami potęguje Korzeniowski przywołaniem w komparansie nazwisk wybitnych autorów, np.:

\footnotetext{
Gdy znowu zachęcony tą łatwością, jaką daje zakończenie na ora, rymujące ze słowami: skora, pora, spora, zmora, wieczora, zapora, i t. d., wolał już był Tassem i składał ośmiowierszową strofę miękką i słodką, jak niektóre Piotra Kochanowskiego, znowu jak na złość pięć zgłosek Eleonory nie właziły żadnym sposobem w wiersz, i łatwiej daleko wsuwała się Beatryks lub Laura (s. 110),
}

które zestawione z wątłymi siłami twórczymi Pawła pogłębiają przepaść między nim a uznanymi autorami.

\section{Porównania charakteryzujące świat przyrody}

Kolejną grupę tematyczną stanowią porównania $\mathrm{z}$ komparatem należącym do pola znaczeniowego "natura”. Zaliczymy tu przede wszystkim porównania związane ze światem roślin (flory). Są to konstrukcje banalne, które np. w wypowiedzi Żyda Abramka uwypuklają charakterystyczną dla niego przesadę, jak również sugerują chęć przypodobania się, zdobycia zaufania Molickiego, co sygnalizuje cytat: „Albo to ja nie wiem, że jasny pan taki porządny gospodarz, i że jaśnie pana zboże suche i niestęchłe, i pszenica żółta jak wosk, i żyto takie wielkie jak groch?” (s. 63).

Niezwykłością skojarzenia zaskakuje natomiast porównanie drzewa do człowieka, będące pochwałą dojrzałości mężczyzny: „Chociaż to już było 
w połowie sierpnia, dąbrowa jaśniała poważną pięknością i uroczym cieniem, bo dąb, jak mężczyzna, najpiękniejszym jest w środku swojego lata" (s. 119). Autor wyzyskuje tu symbolikę dębu konotującego zdrowie, żywotność, siłę $^{23}$, bowiem porównanie $\mathrm{w}$ opisie rezydencji marszałka wydaje się współkreować wizerunek tego mężczyzny nie najmłodszego, ale w sile wieku, dojrzałego ciałem i duchem.

3. Porównania krajobrazowe oraz konstrukcje porównawcze, w których obiekt porównania związany jest $\mathrm{z}$ artefaktami

Wśród porównań charakteryzujących krajobraz odnajdujemy konstrukcje zaskakujące, żartobliwe: „Żal mu się zrobiło Niedolipia (...) tej wody pełnej ryb i stojącej zawsze prawie w jednej mierze, stałej i umiarkowanej, jak dusza filozofa" (s. 60), jak i banalne, odwołujące się do doświadczenia czytelników: "Oświecały go dwa okna weneckie: jedno na dzieciniec, drugie na ową dolinę, gdzie był staw foremny, czysty i okrągławy jak jezioro" (s. 74). Obie konstrukcje komparatywne dopełniają obrazu opisywanego krajobrazu.

$\mathrm{W}$ opisie zimowego stepu wierny realizmowi pisarz przywołuje skojarzenia ze znanym artefaktem, np. „słupy tylko werstowe sterczały, i jak wskazówki busoli, dawały kierunek furmanowi po tem białem i puszystem morzu" (s. 10), doprecyzowując obraz przestrzeni nie zawsze znanej czytelnikowi.

Jednostkowo odnajdujemy porównanie asocjacyjne $\mathrm{w}$ opisie budynku: „Potem poszła do obórki, czystej jak pokój, gdzie stało sześć faworytek pani Skalińskiej, ślicznych tyrolskich krówek" (s. 144). Korzeniowski podkreśla tu ład i porządek panujący w posiadłości marszałka, po raz kolejny pośrednio sygnalizując zalety pracowitego, ceniącego dom i spokój mężczyzny.

\section{Porównania typu sentencjonalnego}

Za B. Mikołajczak przyjmuję, że zaliczone do tej grupy porównania „określają przede wszystkim uczucia miotające duszą człowieka, takie jak: gniew, głupstwo, zdrada, rozkosze, mądrość, ogólnie życie itp."24 .

W „Spekulancie” Korzeniowski wyzyskuje porównania o charakterze sentencjonalnym zarówno w partii dialogowej, gdzie oddają przemyślenia i przeczucia postaci, jak również w opisach. Mają one charakter ogólnych rozważań o świecie i ludzkiej naturze, np. „U nas próżność przygłusza wszystko, i wyłazi wszędzie na wierzch, i panuje nad każdem uczuciem, jak

\footnotetext{
${ }^{23}$ Bartmiński 2009, s. 98.

${ }^{24}$ Mikołajczak 1976, s. 111.
} 
oliwa nad wodą (s. 40)”; „Bo jak głód najlepiej jeść daje, tak fatyga najlepiej ściele”25 (s. 1).

\section{PODSUMOWANIE}

Analizując język powieści Józefa Korzeniowskiego, należy pamiętać o gwałtownym rozwoju literatury $\mathrm{w}$ okresie międzypowstaniowym oraz kolejnych, nie zawsze wyrobionych kulturowo czytelnikach, co podkreśla J. Bachórz:

Społeczną ramą koniunkturalną przełomu rozwojowego, jaki się zaczął przed powstaniem listopadowym, było właczenie się do odbioru literatury szerszego audytorium szlacheckiego oraz nowych środowisk czytelniczych, zwłaszcza inteligencji zawodowej, a od połowy stulecia także rzemieślników. Istotny wpływ na rozszerzanie się rynku powieściowego miały - podobnie jak na Zachodzie - procesy emancypacyjne $\mathrm{w}$ środowisku kobiecym $\mathrm{i}$ aspiracje kobiet $\mathrm{z}$ warstw średnich do udziału w życiu publicznym ${ }^{26}$.

Stąd niewiele $\mathrm{w}$ analizowanym materiale porównań o charakterze erudycyjnym, pełniących funkcję poznawczą, niosących bowiem ze sobą pewną wiedzę o świecie. $Z$ dużą dozą prawdopodobieństwa można przyjąć, że autor powieści jako filolog i pedagog usiłuje zainteresować nimi szersze grono odbiorców. Przede wszystkim jednak sięga po konstrukcje łatwe do odczytania, czasem banalne, podporządkowując je treści utworu. Mają one kreować atmosferę utworu, uplastyczniać opis, zwiększyć jego obrazowość, a przede wszystkim wzmacniać charakterystykę bohaterów, ilustrować ich przeżycia, zamiary i działania. Wydaje się więc uzasadnione, że doświadczony i uznany pedagog wyzyskuje w porównaniach przede wszystkim doświadczenie życiowe projektowanych odbiorców, z umiarem nawiązując do postaci i wydarzeń ze świata historii i kultury.

$\mathrm{W}$ analizowanym materiale odnajdujemy porównania tekstowe, które kreują realistyczny, zbliżony do naturalnego tok rozumowania w narracji, a $\mathrm{w}$ dialogach i listach wprowadzają wrażenie naturalności, a ponadto współtworzą obraz emocji i cech wewnętrznych postaci. Znacznie bardziej interesujące są jednak porównania asocjacyjne, w których pisarz odwołuje się do rzeczywistości pozapowieściowej, sięgając po komparans związany z kręgiem spraw społecznych, światem przyrody ożywionej i nieożywionej.

${ }^{25}$ A. Nowakowska klasyfikuje tego typu konstrukcje jako przysłowia porównawcze. Nowakowska 2005, s. 53

${ }^{26}$ Bachórz 2009, s. 735. 
Charakterystyczne dla Korzeniowskiego jest postawienie w centrum uniwersum przedstawionego człowieka, którego działaniom i emocjom podporządkowany zostaje świat natury oraz artefakty. Konstrukcje komparatywne służą hiperbolizacji lub deprecjacji bohaterów: pomagają interpretować stosunki międzyludzkie, reakcje i wybory postaci, ilustrują ich zachowanie, wzmacniają wady i uwypuklają zalety fizyczne i charakterologiczne. Do świata człowieka odnoszą się również porównania o charakterze sentencjonalnym, pełniące funkcję moralizatorską, bowiem elementy napomnień, przykłady właściwego postępowania, wskazówki dla czytelników są dobrze widoczne w utworach prozatorskich Józefa Korzeniowskiego, profesora Liceum Krzemienieckiego.

\section{SIMILES IN THE LANGUAGE OF JÓZEF KORZENIOWSKI (ON THE EXAMPLE OF COMPARATIVE STRUCTURES USING $A S$ IN THE NOVEL “THE SPECULATOR”)}

\section{Summary}

The article is an attempt to analyse comparative structures using the connective as in the first novel by J. Korzeniowski, The Speculator.

The paper thus scrutinizes 262 comparative structures of that type. Grading and non-grading comparisons were indicated along with the contextual and associative ones. Comparandum was discussed and the concept of semantic fields was also addressed with regards to specific areas such as the human, nature, landscape and artefacts. The sententional type of comparisons was also presented.

The writer rarely uses elements requiring highly developed cultural competencies from his readers. Instead, he tends to employ elements of the phenomenathat are known to them. Two types of comparisons were found: hyperbole or depreciation based on contrasts. Such structures are characterized by enormous functionality: they contribute to the portrayal of the world and to the mood of the novel, enhance the vividness of message the author wishes to convey, individualize the language of the protagonists, and add to the depictions of characters. All that is related to the superior aim in Korzeniowski's writings, which delve into the human individual, their views, behaviours and customs. 


\section{Bibliografia}

Bachórz J. 1979, Realizm bez „chmurnej jazdy”. Studia o powieści Józefa Korzeniowskiego, Warszawa.

Bartmiński J. 2009, Stereotypy mieszkają w języku. Studia etnolingwistyczne, Lublin.

Czachorowska M. 2012, Porównania z komponentem florystycznym w twórczości Bolesława Prusa, [w:] Studia Językoznawcze. Synchroniczne i diachroniczne aspekty badań polszczyzny, 11, Szczecin, s. 47-54.

Fros H., Sowa F. 1982, Twoje imię. Przewodnik onomastyczno-hagiograficzny, Kraków.

Grzeszczuk B. LXI, Z historii konstrukcji porównawczych z jako, jakoż itp., Język Polski 1981, z. 1-2, s. 49-53.

Grzędzielska M. 1971, Małe i wielkie metafory, Pamiętnik Literacki, 62, 4, s. 94-111.

Kawyn S. 1978, Józef Korzeniowski. Studia i szkice, Łódź.

Kopaliński W. 1987, Słownik mitów i tradycji kultury, Warszawa.

Kopaliński W. 1990, Słownik symboli, Warszawa.

Korzeniowski J. 1871, Spekulant, [w:] Dzieła Józefa Korzeniowskiego, wydanie zupełne, pod kierunkiem redakcyi „Kłosów”, Warszawa, 1, s. 1-148.

Korzeniowski J. 1954, Spekulant, [w:] Dzieła wybrane, Kraków, s. 1-207, 407-418.

Kowalski P. 1998, Leksykon znaki świata. Omen, przesąd znaczenie, Warszawa-Wrocław.

Kozaryn D. 2009, Porównanie w języku Mikołaja Reja (na przykładzie porównań z łącznikiem by w Wizerunku własnym człowieka poczciwego), [w:] T. Korpysz, A. Kozłowska (red.), Język pisarzy jako problem lingwistyki, Warszawa, s. 135-147.

Kurkowska H., Skorupka S. 1959, Stylistyka polska. Zarys, Warszawa.

Literatura polska. Przewodnik encyklopedyczny1984, 1, Warszawa.

Mikołajczak B. 1976, Porównania w Faraonie Bolesława Prusa, Studia Polonistyczne III, Poznań, s. 105-114.

Mikołajczak S. 2001, Porównania w powieściach historycznych Henryka Sienkiewicza, Poznańskie Studia Polonistyczne. Seria Językoznawcza VIII (XXVIII), Poznań, s. 87-112.

Mikołajczakowa B., Mikołajczak S. 1996, Porównania w „Quo vadis” Henryka Sienkewicza - nierocznicowe uwagi w stulecie wydania, Poznańskie Studia Polonistyczne. Seria Językoznawcza III, Poznań, s. 67-90.

Nowakowska A. 2005, Świat roślin w polskiej frazeologii, Wrocław.

Siekierska K. 1981, Porównania w „Wojnie chocimskiej” Wacława Potockiego i w „Pamiętnikach" Jana Chryzostoma Paska, Polonica, 7, s. 233-254.

Słownik języka polskiego 1861, wydany staraniem i kosztem M. Orgelbranda, I-II, Wilno.

Słownik literatury polskiej XIX wieku 2009, red. J. Bachórz, A. Kowalczykowa, Wrocław.

Słownik terminów literackich 1988, red. J. Sławiński, Wrocław-Warszawa-Kraków-Gdańsk-Łódź.

Ścibek J. 2013, O porównaniach z komponentem odsyłającym do antyku grecko-rzymskiego w Beniowskim Juliusza Słowackiego, [w:] U. Sokólska (red.), Tekst - akt mowy - gatunek wypowiedzi, Białystok, s. 99-121.

Walczak B., Powieść XIX i XX wieku - obraz języka doby nowopolskiej, Polonistyka 9, 1989, s. $664-673$.

Walczak B. 2014, Tekst artystyczny jako podstawa źródłowo - materiałowa na gruncie historycznych subdyscyplin językoznawczych, [w:] E. Skorupska-Raczyńska, M. Maczel, J. Żurawska-Chaszczewska (red.), Tekst artystyczny w badaniach lingiwstycznych, Gorzów Wielkopolski, s. 219-232.

Wielka ilustrowana encyklopedja powszechna, Kraków 1929-1938, 1-25.

Wierzbicka A. Porównanie - gradacja - metafora, Pamiętnik Literacki, LXII, z. 4, s. 127-147.

Witkowska A. 1986, Literatura romantyzmu, Warszawa.

Zarębina M. 1991, Porównania w „Anielce” i „Placówce” Bolesława Prusa, Polonica, XV, s. 131-144. 
Żurawska-Chaszczewska J. 2015, Językowa kreacja kobiecego ciała w powieściach Spekulant i Kollokacja Józefa Korzeniowskiego, [w:] Współczesny i dawny obraz kobiety w języku i literaturze, Szczecin, s. 381-393. 